\title{
POTENSI AKUMULASI INSEKTISIDA KLORPIRIFOS ETIL DALAM JARINGAN TUBUH IKAN NILA (Oreochromis niloticus)
}

\author{
Imam Taufik*), Santosa Koesoemadinata*), Sutrisno*), dan Asep Nugraha**)
}

\begin{abstract}
ABSTRAK
Pengujian potensi akumulasi insektisida klorpirifos etil dalam jaringan tubuh ikan nila dilakukan dalam kondisi laboratorium. Tujuan pengujian adalah untuk menentukan nilai BCF (Bioconcentration Factor) senyawa bahan aktif insektisida tersebut terhadap ikan nila. Pengujian toksisitas akut dilakukan untuk mendapatkan nilai $\mathrm{LC}_{50}-96$ jam, atas dasar mana konsentrasi uji dalam penentuan nilai BCF tersebut digunakan $\left(=0,3 \times \mathrm{LC}_{50}-96 \mathrm{jam}\right)$. Penelitian daya akumulasi insektisida klorpirifos etil dilakukan dalam 15 unit akuarium yang masing-masing diisi $50 L$ air dengan konsentrasi subletal insektisida $(=0,174 \mathrm{mg} / \mathrm{L})$. Tiap wadah diisi satu ekor ikan nila dengan bobot 52,4 $\pm 1,5$ g per ekor. Waktu dedah ikan uji adalah $1,3,7,10$, dan 14 hari. Pengambilan contoh ikan dan larutan uji dilakukan pada setiap periode dedah. Residu klorpirifos etil dalam contoh dianalisis dengan menggunakan alat Kromatografi Gac (KG). Perkiraan nilai BCF insektisida klorpirifos etil pada ikan nila terjadi setelah waktu dedah 14 hari adalah 308 . Hasil tersebut menunjukkan bahwa potensi akumulasi insektisida klorpirifos etil cukup tinggi pada ikan nila.
\end{abstract}

ABSTRACT: Accumulative potential of the insecticide ethyl chlorpyrifos on the tissue of nile tilapia (O. niloticus). By: Imam Taufik, Santosa Koesoemadinata, Sutrisno, and Asep Nugraha

Accumulative potential of the insecticide ethyl chlorpyrifos on the tissue of nile tilapia, was studied out in laboratory condition. The aim of the experiment was to determine the Bioconcentration Factor (BCF) of the insecticide in nile tilapia. Acute toxicity test of the insecticide to the nile tilapia was carried out to obtain the 96hr-LC ${ }_{50}$ value, from which data on the actual sublethal concentration used in the determination of the BCF will be derived $\left(=0.3 \times 96 h r-L C_{50}\right)$. Experiment on the accumulation rate of ethyl chlorpyrifos in nile tilapia was carried out in 15 glass containers, each contained $15 \mathrm{~L}$ of test solution, i.e. insecticide concentration of $0.174 \mathrm{mg} / \mathrm{L}$, and one test fish (weight: $52.4 \pm 1.5 \mathrm{~g}$ ). Exposure periods used in the experiment were 1, 3, 7, 10, and 14 days. Fish and water samples were collected for every exposure period, and analysed for ethyl chlorpyrifos residue using Gas Chromatograph (GC). Estimated BCF value for the insecticide was 308. The insecticide: ethyl chorpyrifos was considered to be highly accumulative in fish tissues.

KEYWORDS: $\quad$ accumulation, Bioconcentration Factor (BCF), ethyl chlorpyrifos

\section{PENDAHULUAN}

Indonesia sebagai salah satu negara yang berusaha meningkatkan produksi pangan telah banyak menggunakan pestisida, bahkan menduduki urutan ketiga terbesar di Asia dalam penggunaan pestisida setelah RRC dan India (Soerjani, 1990). Pestisida sebagai faktor tambahan telah digunakan untuk memanipulasi lingkungan dengan tujuan untuk memperbaiki kualitas lingkungan dengan mengendalikan jasad pengganggu (hama) dan penyakit yang dapat menurunkan produksi (Wudianto, 1997).

Dampak penggunaan pestisida yang sering terabaikan adalah tercemarnya lingkungan perairan akibat jatuhnya bahan aktif pestisida ke dalam perairan, oleh karena itu pestisida dianggap sebagai sumber pencemaran yang potensial bagi dunia perikanan. Dalam konsentrasi tinggi bahan aktif pestisida yang masuk ke dalam air dapat langsung mematikan ikan serta biota akuatik lainnya, sedangkan dalam konsentrasi yang rendah (subletal) akan dapat terakumulasi dalam jaringan tubuh biota akuatik. Hal tersebut disebabkan air, sedimen, dan biota akuatik (khususnya ikan, siput dan kerang) merupakan media dan akumulator residu pestisida yang baik (Sunarjo, 1990).

Klorpirifos etil adalah salah satu senyawa kimia yang banyak digunakan sebagai bahan aktif formulasi insektisida untuk mengendalikan hama tanaman, antara lain: Atherigona exiguna, Spodoptera maurita, dan Agrotis sp. (Baehaki, 1993). Bahan aktif tersebut termasuk ke dalam golongan organofosfat yang

\footnotetext{
- Peneliti pada Balai Penelitian Perikanan Air Tawar, Sukamandi

-) Peneliti pada Balai Penelitian Bioteknologi Tanaman Pangan, Bogor
} 
bersifat lebih toksik terhadap hewan bertulang belakang dibanding dengan senyawa organoklorin (Sastroutomo, 1992).

Ikan nila, Oreochromis niloticus termasuk komoditas perikanan air tawar yang penting sebagai salah satu sumber protein hewani masyarakat. Kegiatan budi daya ikan tersebut banyak dilakukan oleh petani di berbagai perairan, seperti: kolam, waduk, dan tambak air payau. Perairan tersebut merupakan wilayah yang kritis terkena pencemaran bahan aktif pestisida yang berasal dari berbagai aktivitas pertanian di lingkungan sekitarnya. Tercemarnya perairan oleh pestisida pada konsentrasi yang tinggi akan mudah terdeteksi dengan matinya berbagai organisme perairan termasuk ikan yang dibudidayakan, akan tetapi pencemaran pada konsentrasi rendah tidak dapat dideteksi secara visual untuk itu diperlukan analisis toksikologi dan kimia di laboratorium. Darnpak subletal pestisida yang penting adalah residu pestisida di dalam jaringan tubuh, oleh karena itu informasi mengenai potensi akumulasi klorpirifos etil dalam tubuh ikan perlu diketahui sebagai data pendukung bagi penerapan kebijakan penggunaan pestisida di sektor perikanan.

\section{BAHAN DAN METODE}

Percobaan dilakukan di Laboratorium Toksikologi Balai Penelitian Perikanan Air Tawar-Sukamandi, bekerja sama dengan Balai Penelitian Bioteknologi Tanaman Pangan-Bogor.

Wadah percobaan untuk uji toksisitas letal menggunakan 21 unit akuarium berukuran $40 \times 20 x$ $26 \mathrm{~cm}^{3}$ (pxlxt), yang masing-masing diisi air sebanyak $10 \mathrm{~L}$ dan dilengkapi dengan aerasi. Hewan uji yang digunakan adalah ikan nila dengan ukuran bobot 2,75 $\pm 0,3$ g/ekor.

Uji daya akumulasi menggunakan wadah berupa 15 akuarium berukuran $70 \times 35 \times 50 \mathrm{~cm}^{3}$ ( $\mathrm{px}$ (xt) yang ditempatkan secara paralel, masing-masing akuarium diisi dengan air sebanyak $50 \mathrm{~L}$. Hewan uji berupa ikan nila dengan ukuran bobot 52,4 $\pm 1,5$ g/ekor. Untuk meningkatkan efektivitas dan akurasi penyerapan bahan uji ke dalam tubuh organisme, maka hewan uji didedahkan per-individu (kepadatan 1 ekor/50 L air). Selama pendedahan tidak dilakukan pergantian air.

Bahan uji yang digunakan adalah formulasi insektisida dengan kandungan bahan aktif $200 \mathrm{~g} / \mathrm{L}$ klorpirifos etil (selanjutnya ditulis klorpirifos). Bahan uji tersebut merupakan produk pestisida komersil yang telah umum beredar di pasar. Bahan uji dilarutkan dengan $10 \mathrm{~mL}$ aseton ditambah aquades sehingga diperoleh larutan induk sebanyak $100 \mathrm{~mL}$ dengan konsentrasi $10.000 \mathrm{mg} / \mathrm{L}$.

\section{Uji Toksisitas Letal}

Untuk mengetahui nilai $\mathrm{LC}_{50}-96$ jam sebagai dasar penentuan konsentrasi perlakuan maka dilakukan uji toksisitas letal dengan metoda uji hayati (bioassay) melalui dua tahap (Busvine, 1971). Pertama, uji pendahuluan yaitu uji untuk menentukan ambang daya racun akut pestisida terhadap hewan uji dengan cara menentukan kisaran kritis (critical range) yaitu konsentrasi ambang bawah ( $\mathrm{LC}_{100}-48$ jam) dan ambang atas $\left(\mathrm{LC}_{100}-24 \mathrm{jam}\right)$ klorpirifos yang besarnya berkisar antara 1,$0 ; 3,0 ; 6,0 ;$ dan $10,0 \mathrm{mg} / \mathrm{L}$ atau merupakan kelipatan basis 10 dari angka-angka tersebut dengan waktu dedah selama 48 jam (Komisi Pestisida, 1983). Kedua, uji lanjutan yaitu untuk menentukan Median Lethal Concentration $\left(\mathrm{LC}_{50}\right)$ dengan jumlah konsentrasi sebanyak 7 tingkat (termasuk kontrol) yang besarnya berada antara nilai ambang bawah dan ambang atas yang nilainya dipilih secara berurutan berdasarkan deret logaritmik (Tabel 1) dengan waktu dedah 96 jam. Masing-masing konsentrasi dalam 3 ulangan dengan jumlah hewan uji untuk setiap akuarium uji hayati sebanyak 10 ekor.

\section{Median Lethal Concentration (LCG ${ }_{50}$ )}

Nilai $L_{50}$ ditentukan dengan analisis probit yang mengacu pada metode Litchfield \& Wilcoxon (1949). Analisis dilakukan dengan mengeplot konsentrasi insektisida dengan mortalitas ikan pada grafik log probit (H.W. Peel \& Co, Chartwell. Reg. No. 5574) di mana mortalitas pada skala probit dan konsentrasi insektisida pada skala logaritma. Hasil plot pada garis menunjukkan persentase mortalitas harapan. Kemudian dilakukan koreksi antara mortalitas yang dicatat dengan mortalitas yang diharapkan melalui nilai $(\mathrm{Chi})^{2}$ yang ditentukan dengan persamaan:

$$
(\text { Chi })^{2}=\left(M^{\prime}-M\right)^{2} / M^{\prime}\left(100-M^{\prime}\right)
$$

di mana:

$M=$ mortalitas hewan uji tercatat atau dikoreksi

$M^{\prime}=$ mortalitas hewan uji yang diharapkan

Bila $(\mathrm{Chi})^{2}$ hitung $<(\mathrm{Chi})^{2}$ tabel berarti bahwa heterogenitas data tidak nyata (letal garis grafik telah tepat) dan sebaliknya.

\section{Uji Daya Akumulasi}

Sebagai perlakuan pada uji daya akumulasi adalah sebagai berikut (Kanazawa, 1979): hewan uji didedahkan dalam air dengan konsentrasi insektisida klorpirifos sebesar $30 \%$ dari nilai $\mathrm{LC}_{50}-96$ jam dengan waktu dedah: $1,3,7,10$, dan 14 hari di mana konsentrasi tersebut merupakan konsentrasi tertinggi yang tidak mematikan hewan uji. Pada setiap waktu dedah dilakukan pengambilan contoh ikan uji dan 
Tabel 1. Skala logaritmik konsentrasi pestisida secara berurutan (Duodoroff et al., 1951)

Table 1. Logaritmic scale of pesticide concentration respectively (Duodoroff et al., 1951)

\begin{tabular}{ccccc}
\hline $\begin{array}{c}\text { Kolom 1 } \\
\text { Column 1* }\end{array}$ & $\begin{array}{c}\text { Kolom 2 } \\
\text { Column 2 }\end{array}$ & $\begin{array}{c}\text { Kolom 3* } \\
\text { Column 3 }\end{array}$ & $\begin{array}{c}\text { Kolom 4* } \\
\text { Column 4 }\end{array}$ & $\begin{array}{c}\text { Kolom 5* } \\
\text { Column 5* }\end{array}$ \\
\hline 10.0 & - & - & - & - \\
- & - & - & - & 8.7 \\
- & - & - & 7.5 & - \\
- & - & - & - & 6.5 \\
- & - & 5.6 & - & - \\
- & - & - & - & 4.9 \\
- & - & - & 4.2 & - \\
- & - & - & - & 3.7 \\
- & 3.2 & - & - & - \\
- & - & - & - & 2.8 \\
- & - & - & 2.4 & - \\
- & - & - & - & 2.1 \\
- & - & 1.8 & - & - \\
- & - & - & - & 1.55 \\
- & - & - & 1.35 & - \\
- & - & - & - & 1.15 \\
1.0 & - & - & - & - \\
\hline
\end{tabular}

* Angka-angka dalam kolom dapat diperkalikan atau dibagi dengan angka basis 10 , misalnya $10^{-3}, 10^{-2}$, $10^{2}, 10^{3}$ dan seterusnya

Figures in columns can be multiplied by a factor of 10 , example: $10^{-3}, 10^{-2}, 10^{2}, 10^{3}$

* Umumnya pemakaian konsentrasi pada kolom 2,3, dan 4 sudah memadai untuk suatu pengujian pestisida Generally use of concentrations in column 2,3, and 4 is inefficient for pesticide toxicity test

larutan uji untuk dianalisis kandungan residu insektisida.

Seluruh bagian ikan dari setiap perlakuan dirajang dan dihaluskan, kemudian masing-masing contoh diambil sebanyak $10 \mathrm{~g}$ dan dimasukkan ke dalam tabung kertas soxhlet, kemudian diekstrak menggunakan pelarut aseton sebanyak $100 \mathrm{~mL}$ pada alat soxhlet. Ekstraksi berlangsung selama 6 jam pada suhu $80^{\circ} \mathrm{C}$. Setelah 6 jam, hasil ekstraksi diuapkan dalam evaporator pada suhu $45^{\circ} \mathrm{C}$.

Residu insektisida yang diperoleh dari hasil evaporasi dipindahkan ke dalam corong pemisah 150 $\mathrm{mL}$ dengan bantuan pelarut $\mathrm{n}$-heksan $25 \mathrm{~mL}$, kemudian diekstraksi dengan $25 \mathrm{~mL}$ pelarut asetonitril sebanyak 3 kali. Lapisan $n$-heksan akan terbentuk di sebelah atas sedangkan lapisan asetonitril di sebelah bawah.

Lapisan asetonitril hasil ekstrak 3 kali kemudian diuapkan/dipekatkan dalam evaporator pada suhu yang sama dengan terdahulu. Larutan residu hasil evaporasi selanjutnya dilarutkan dengan pelarut $n$ heksan sebanyak $5 \mathrm{~mL}$ dan disuntikkan ke dalam kolom kromatografi dan dielusi dengan eluen campuran $n$-heksan + aceton $(9+1)$. Eluat yang mengandung residu insektisida ditampung dalam labu beralas datar $125 \mathrm{~mL}$. Eluat dipekatkan hingga agak bening. Eluat yang hampir kering dimasukkan ke dalam tabung uji dengan pelarut aseton hingga volume menjadi $5 \mathrm{~mL}$. Dari larutan tersebut ditetapkan kandungan residu insektisida klorpirifos (organofosfat) dengan alat Gas Kromatografi yang dilengkapi Electron Capture Detector(ECD) (Kanazawa et al., 1985).

Analisis contoh air sebanyak $200 \mathrm{~mL}$ dilakukan melalui absorben SEP-PAK $\mathrm{C}_{18}$. Residu yang terikat pada absorben $\mathrm{C}_{18}$ dibilas dengan $5 \mathrm{~mL}$ aseton. Eluat ditampung langsung dalam tabung uji $10 \mathrm{~mL}$. Dari eluat yang dihasilkan ditetapkan residu klorpirifos dengan alat Gas Kromatografi yang dilengkapi ECD.

Kandungan residu klorpirifos dalam contoh ikan dan air berdasarkan rumus:

$$
\operatorname{Residu}(\mathrm{mg} / L)=\frac{A c \times \text { Vis } \times K s \times V f c}{A s \times \text { Vic } \times B \times R}
$$

di mana:

Ac $=$ area contoh

As = area standar

Vic $=$ volume injeksi contoh

Vis $=$ volume injeksi standar 
$\mathrm{Ks}=$ konsentrasi standar $(\mathrm{mg} / \mathrm{L})$

$\mathrm{B}=$ bobot awal/volume awal ( $\mathrm{mg}$ atau $\mathrm{mL}$ )

$\mathrm{Vfc}=$ volume final contoh $(\mathrm{mL})$

$\mathrm{R} \quad=\operatorname{recovery}(\%)$

Kondisi kromatografi gas cair untuk analisis residu insektisida klorpirifos adalah sebagai berikut:

Tipe kromatografi gas cair : Shimadzu GC-4 CM

Suhu injektor $\quad: 240^{\circ} \mathrm{C}$

Suhu kolom $\quad: 220^{\circ} \mathrm{C}$

Jenis kolom : OV-17 Chromosorb

WAW 3 meter

Kecepatan alir gas $\mathrm{N}_{2}: 40 \mathrm{~mL} /$ menit

Jenis detektor : ECD

Sensitivitas $\quad: 10^{2} \times 4 \mathrm{MW}$

Faktor biokonsentrasi (Bioconcentration Factor) $B C F)$ ditentukan dari hasil analisis tersebut yaitu rasio antara konsentrasi residu klorpirifos dalam tubuh dan dalam air (Specie \& Hamelink, 1985).

\section{HASIL DAN BAHASAN}

\section{Toksisitas Letal}

Daya racun letal adalah daya racun dari bahan beracun yang dapat mematikan hewan uji dengan cara kontak langsung. Biasanya daya racun letal pada ikan beracun. Ambang atas $(1,0 \mathrm{mg} / \mathrm{L})$ merupakan konsentrasi insektisida klorpirifos yang mematikan semua hewan uji dalam waktu dedah 24 jam.

Kematian ikan nila terjadi akibat masuknya insektisida ke dalam tubuh melalui kulit, saluran pernafasan, dan saluran pencernaan dengan mengikat enzim asetilkholinesterase yang berfungsi mengatur kerja saraf. Bila enzim yang berada dalam darah tersebut terikat maka kerja saraf menjadi terganggu, akibatnya gerak otot tidak dapat dikendalikan, sehingga timbul kekejangan, lumpuh, atau pingsan yang dapat menyebabkan kematian (Natawiguna, 1989). Introduksi insektisida ke dalam jaringan tubuh juga dapat terjadi melalui (1) penelanan makanan yang terkontaminasi, (2) pengambilan dari air yang melewati membran insang, (3) difusi kutikular, dan (4) penyerapan langsung dari sedimen (Livingston, 1977).

Berdasarkan deret logaritmik Duoduroff et al. (1951), konsentrasi klorpirifos yang dipilin pada uji lanjutan adalah: 0,$42 ; 0,56 ; 0,75 ; 1,00 ; 1,35$; dan 1,80 $\mathrm{mg} / \mathrm{L}$ dengan kontrol $(0 \mathrm{mg} / \mathrm{L})$ sebagai pembanding. Jumlah mortalitas ikan uji setiap konsentrasi selama waktu dedah 96 jam terlihat pada Tabel 2.

Dari Tabel 2 terlihat bahwa semakin tinggi konsentrasi klorpirifos dalam air akan mengakibatkan bertambahnya mortalitas ikan. Hasil analisis statistik mem-

Tabel 2. Mortalitas ikan nila pada uji lanjutan setelah waktu dedah 96 jam dalam larutan klorpirifos dengan konsentrasi yang berbeda

Table 2. Mortality of nile tilapia on confirmatory test after exposed in chlorpyrifos of different concentration for 96-hours

\begin{tabular}{|c|c|c|c|c|c|}
\hline \multirow{2}{*}{$\begin{array}{c}\text { Konsentrasi }(\mathrm{mg} / \mathrm{L}) \\
\text { Concentration }(\mathrm{mg} / \mathrm{L})\end{array}$} & \multirow{2}{*}{$\begin{array}{c}\text { Jumlah ikan uji (ekor) } \\
\text { Number of fish }\end{array}$} & \multicolumn{3}{|c|}{ Ulangan (Replicates) } & \multirow{2}{*}{$\begin{array}{l}\text { Mortalitas \% } \\
\text { Mortality (\%) }\end{array}$} \\
\hline & & 1 & 2 & 3 & \\
\hline 0 (Kontrol) (Control) & 30 & 0 & 0 & 0 & $0.00^{a}$ \\
\hline 0.42 & 30 & 6 & 3 & 4 & $4.33^{b}$ \\
\hline 0.56 & 30 & 4 & 5 & 5 & $4.67^{b}$ \\
\hline 0.75 & 30 & 6 & 5 & 6 & $5.67^{b}$ \\
\hline 1.00 & 30 & 8 & 4 & 6 & $6.00^{\mathrm{c}}$ \\
\hline 1.35 & 30 & 7 & 8 & 6 & $7.00^{\mathrm{c}}$ \\
\hline 1.80 & 30 & 10 & 8 & 10 & $9.33^{\mathrm{d}}$ \\
\hline
\end{tabular}

* Angka yang diikuti huruf sama menunjukkan tidak beda nyata $(P<0,05)$

* The number followed by the same symbol means are not significantly different $(P<0.05)$

akan terlihat setelah waktu dedah 96 jam (Tanjung, 1982). Dari uji pendahuluan diketahui bahwa kisaran kritis insektisida klorpirifos terhadap ikan nila adalah antara $0,1 \mathrm{mg} / \mathrm{L}\left(\mathrm{LC}_{0}-48 \mathrm{jam}\right)$ dan $1,0 \mathrm{mg} / \mathrm{L}\left(\mathrm{LC}_{100}-24\right.$ jam). Nilai ambang bawah $(0,1 \mathrm{mg} / \mathrm{L})$ adalah tingkat konsentrasi klorpirifos yang tidak mematikan hewan uji dalam waktu dedah 48 jam; konsentrasi tersebut masih dalam kisaran toleransi ikan nila terhadap bahan perlihatkan bahwa konsentrasi klorpirifos berpengaruh nyata $(P<0,05)$ terhadap mortalitas ikan nila dibanding dengan kontrol, bahkan antara beberapa perlakuan.

\section{Median Lethal Concentration $\left(\mathrm{LC}_{50}\right)$}

Hasil analisis dengan mengeplot konsentrasi insektisida dan mortalitas hewan uji pada grafik log 
probit menunjukkan bahwa mortalitas ikan nila berbanding lurus dengan konsentrasi klorpirifos yang berarti bahwa semakin tinggi konsentrasi klorpirifos akan mengakibatkan peningkatan mortalitas ikan nila. Nilai koreksi $(\mathrm{Chi})^{2}$ hitung adalah 5,388 dengan derajat bebas 4 , sehingga nilai $(\mathrm{Chi})^{2}$ tabel adalah 9,49 sehingga $(\mathrm{Chi})^{2}$ hitung $<(\mathrm{Chi})^{2}$ tabel yang berarti bahwa heterogenitas data tidak nyata (letal garis grafik telah tepat).

Melalui analisis probit dari nilai-nilai konsentrasi klorpirifos dan mortalitas ikan nila diketahui bahwa nilai $L_{50}-96$ jam adalah sebesar $0,580 \mathrm{mg} / \mathrm{L}$ dengan limit atas 0,846 mg/L dan limit bawah 0,396 mg/L di mana pada konsentrasi tersebut mortalitas ikan nila menunjukkan persentase tepat pada skala probit $50 \%$.

Jika diklasifikasikan berdasarkan daya racun pestisida terhadap ikan (Komisi Pestisida, 1983), maka klorpirifos termasuk ke dalam insektisida dengan tingkat daya racun sangat tinggi dengan nilai $\mathrm{LC}_{50}{ }^{-96} \mathrm{jam}$ adalah $<1 \mathrm{mg} / \mathrm{L}$. Tingginya toksisitas ini berkaitan erat dengan sifat dari insektisida tersebut yang termasuk ke dalam golongan organofosfat yang mempunyai sifat sangat cepat dan efektif menyerang sistem saraf dan menyebabkan inaktifnya asetikholinesterase yang berperan untuk mengatur pemindahan impuls saraf (Ewen \& Stephenson, 1977 dalam Darmiatun, 1993)

\section{Daya Akumulasi Insektisida}

Melalui uji toksisitas letal diketahui bahwa nilai $\mathrm{LC}_{50}-96$ jam insektisida klorpirifos terhadap ikan nila adalah $0,580(0,396-0,846) \mathrm{mg} / \mathrm{L}$, selanjutnya untuk uji daya akumulasi insektisida digunakan konsentrasi $30 \%$ dari $\mathrm{LC}_{50}-96$ jam yaitu sebesar $0,174 \mathrm{mg} / \mathrm{L}$. Konsentrasi tersebut merupakan konsentrasi tertinggi klorpirifos yang tidak mematikan ikan nila.

Hasil analisis residu insektisida klorpirifos dalam tubuh ikan nila dan air untuk setiap waktu dedah dapat terlihat pada Tabel 3.
Dari Tabel 3 diketahui bahwa daya akumulasi pestisida dalam tubuh ikan berlangsung melalui proses bioakumulasi yaitu kemampuan bertambahnya residu pestisida di dalam tubuh atau bagian tubuh organisme yang terjadi karena perbandingan pengambilan/ penyerapan pestisida melampaui kemampuan organisme tersebut untuk menghilangkan pestisida. Proses penyerapan pestisida ke dalam tubuh ikan dapat terjadi melalui permukaan tubuh, pernapasan atau masuk bersama makanan (Specie \& Hamelink, 1985).

Penyerapan insektisida secara intensif oleh ikan nila terjadi pada hari pertama dengan kandungan residu sebesar 0,4822 yang mengakibatkan berkurangnya konsentrasi insektisida di dalam air menjadi 0,0017 mg/L. Proses tersebut dapat berlangsung dalam waktu singkat ( 24 jam) karena ikan merupakan akumulator residu pestisida yang baik (Sunarjo, 1990). Periode ini merupakan fase adaptasi fisiologi ikan terhadap tekanan lingkungan dengan cara menyerap sebanyak-banyaknya zat asing yang ada untuk disesuaikan dengan kondisi cairan dalam tubuhnya.

Menurut Wardoyo (1977), setelah waktu dedah tiga hari ikan dapat beradaptasi dan sanggup memetabolisir bahan beracun seperti pestisida. Pada hari ke-7 secara perlahan ikan mampu mengeluarkan insektisida sehingga konsentrasinya dalam tubuh menurun $(0,1919 \mathrm{mg} / \mathrm{L})$ seiring dengan peningkatan konsentrasi insektisida dalam air (0,0027 mg/L). Pada hari ke-10 konsentrasi insektisida dalam tubuh ikan hanya tinggal $0,062 \mathrm{mg} / \mathrm{L}$ dan relatif konstan sampai hari ke-14 (0,0616 mg/L), dernikian pula dalam air konsentrasi insektisida menurun pada hari ke-10 dan konstan sampai hari ke-14. Proses pelepasan bahan aktif insektisida dari dalam tubuh ikan tidak dapat berlangsung terus-menerus karena kemampuan ikan nila untuk menyerap klorpirifos lebih besar dibanding kemampuan untuk mengeluarkan bahan aktif tersebut, sehingga terjadi bioakumulasi klorpirifos di dalam tubuh ikan (Specie \& Hamelink, 1985). Hal tersebut

Tabel 3. Konsentrasi residu insektisida klorpirifos ( $\mathrm{mg} / \mathrm{L})$ dalam air dan tubuh ikan pada setiap waktu dedah (hari)

Table 3. Insecticide residue concentrasi of ethyl chlorpyrifos ( $\mathrm{mg} / \mathrm{L})$ in the water and fish after exposed in different exposure time (day)

\begin{tabular}{ccc}
\hline $\begin{array}{c}\text { Waktu dedah (hari) } \\
\text { Exposure time (day) }\end{array}$ & \multicolumn{2}{c}{ Residu (Residue) (mg/L) } \\
Ikan (Fish) & Air (Water) \\
\hline 0 (Kontrol) (Control) & 0.0 & 0.0328 \\
1 & 0.4822 & 0.0017 \\
3 & 0.4819 & 0.0006 \\
7 & 0.1919 & 0.0027 \\
10 & 0.0620 & 0.0002 \\
14 & 0.0616 & 0.0002 \\
\hline
\end{tabular}


terjadi pada periode dedah 10 dan 14 hari di mana berkurangnya konsentrasi insektisida dalam tubuh ikan tidak lagi diimbangi dengan penambahan konsentrasi insektisida dalam air (Tabel 3 dan Gambar 1).

Setelah waktu dedah mencapai 14 hari, konsentrasi klorpirifos di dalam tubuh ikan nila dan di air telah stabil dengan nilai konsentrasi sebesar 0,0616 dan $0,0002 \mathrm{mg} / \mathrm{L}$. Berarti bahwa dalam waktu dedah 14 hari telah tercapai Bioconcentration Factor (BCF) yang merupakan nilai perbandingan antara konsentrasi residu pestisida dalam tubuh ikan dengan konsentrasi residu pestisida dalam air pada saat konsentrasi tersebut dalam kondisi/fase yang relatif stabil (Rand \& Petrocelli, 1985 dalam Holland, 1996; Specie \& Hamelink, 1985) dan nilai tersebut adalah sebesar 308. Hasil ini sesuai dengan pernyataan Barron \& Woodburn (1995) bahwa nilai BCF untuk klorpirifos terhadap invertebrata dan ikan air tawar berkisar antara 42 sampai 5100. tubuh ikan dan organisme akuatik lainnya yang hidup di suatu perairan hanya dengan menghitung konsentrasi pestisida di dalam air. Hal tersebut akan sangat memudahkan untuk digunakan dalam memperkirakan jumlah residu pestisida yang terkandung dalam ikan yang hidup dalam perairan umum seperti danau, waduk, maupun sungai.

\section{KESIMPULAN}

1. Kisaran kritis insektisida klorpirifos terhadap ikan nila adalah antara $0,1 \mathrm{mg} / \mathrm{L}$ dan $1,0 \mathrm{mg} / \mathrm{L}$ dengan nilai LC ${ }_{50}-96$ jam sebesar $0,58(0,396-0,846) \mathrm{mg} / \mathrm{L}$.

2. Berdasarkan klasifikasi daya racun pestisida terhadap ikan, klorpirifos termasuk insektisida berdaya racun sangat tinggi dengan nilai $\mathrm{LC}_{50}-96 \mathrm{jam}$ $<1 \mathrm{mg} / \mathrm{L}$

3. BCF insektisida klorpirifos terhadap ikan nila dapat tercapai dalam waktu dedah 14 hari dengan nilai
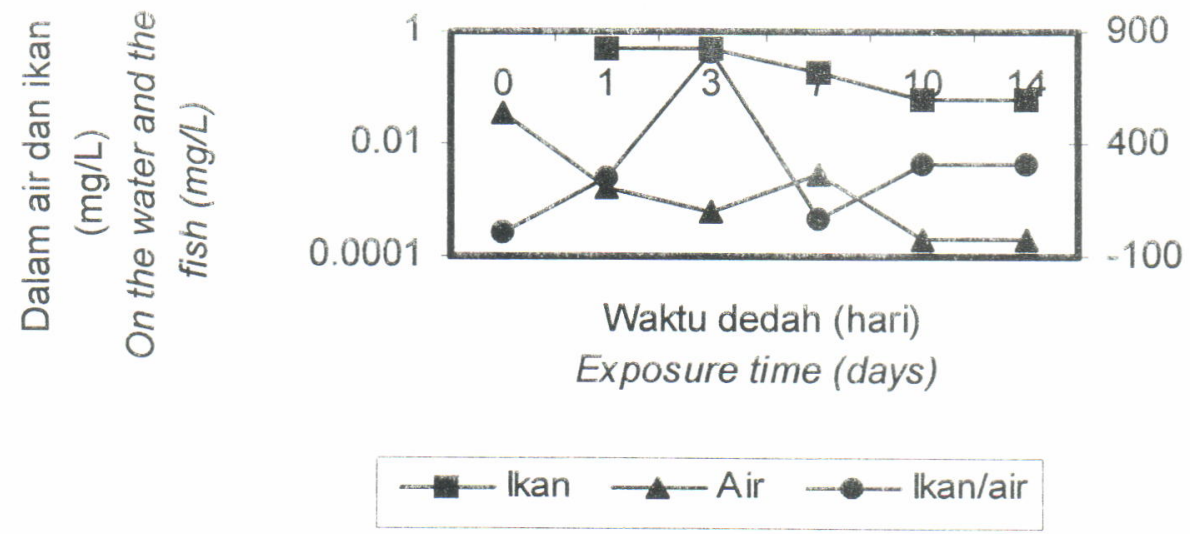

Gambar 1. Konsentrasi klorpirifos ( $\mathrm{mg} / \mathrm{L}$ ) dalam tubuh ikan dan air serta nilai perbandingan untuk setiap waktu dedah (hari)

Figure 1. Residue concentration ( $m g / L$ ) of ethyl chlorpyrifos on the water and the fish tissue and comparative value (fish/water) in any exposure time (days)

Tsuda et al. (1992) mendapatkan nilai BCF klorpirifos terhadap ikan mas (Cyprinus carpio) dalam waktu pemaparan 14 hari sebesar 460, sedangkan pada ikan bluegill (Lepomis macrochirus) sebesar 100 (Eaton et al., 1985) dan pada Anguilla anguilla adalah 230 (Douglas \& Bell, 1990). Adanya perbedaan tersebut karena nilai BCF sangat tergantung kepada spesies ikan, konsentrasi pestisida, dan kondisi lingkungan perairan (Barron \& Woodburn, 1995).

BCF menggambarkan kemampuan terakumulasinya suatu jenis bahan aktif pestisida di dalam lingkungan. Dengan mengetahui nilai BCF dapat dijadikan pedoman untuk memperkirakan konsentrasi residu pestisida yang terkandung di dalam jaringan sebesar 308 yang berarti bahwa bahan aktif tersebut berpotensi akumulasi cukup tinggi pada ikan nila

\section{DAFTAR PUSTAKA}

Baehaki. 1993. Insektisida Pengendali Hama Tanaman. Angkasa, Bandung. $45 \mathrm{pp}$.

Barron, M.G. and K.B. Woodburn. 1995. Ecotoxicology of chlorpyrifos. Review of Environmental Contamination and Toxicology. Springer-Verlag New York, Inc. 144: $93 \mathrm{pp}$

Busvine, J.R. 1971. Acritical riview of techniques for testing insecticides. Common Wealth Agricultural Boreoux. $345 \mathrm{pp}$.

Darmiatun, S. 1993. Toksisitas, Efek Patologik, dan Kandungan $\mathrm{Pb}$ Asetat dan $\mathrm{Zn}$ Asetat pada Ikan Nila 
(Oreochromis niloticus, Trewavas). Fakultas BiologiUGM. Yogyakarta. $115 \mathrm{pp}$.

Doudoroff, T., B.G. Anderson, C.E. Burdick, P.S. Galtsoff, W.B. Hart, R. Petrick, E.R. Strong, E.W. Surber, and W.M. Van Horn. 1951. Bioassay Method for the Evaluation of Acute Toxicity of Industrial Wastes to Fish. Sewage and Industrial Wastes, 23(11): 1380--1397.

Douglas, M.T. and I.B. Bell. 1990. The bioaccumulation and depuration of chlorpyrifos by the eel (Anguilla anguilla). Tech. Rep. GHE-T-28. DowElanco, Indianapolis. p.403--421.

Eaton, J., J. Arthur, R. Hermanutz, R. Kiefer, R, Muller, R. Anderson, R. Erickson, B. Nordling, J. Rogers, and H. Pritchard. 1985. Biological effect of continous and intermittent dosing of outdoor experiment streams with chlorpyrifos. In: R.C. Bahner and D.J. Hansen (eds). Aquatic Toxicology and Hazard Assesment: $8^{\text {th }}$ Symposium. ASTM STP 891. American Society for Testing and Materials, Philadelpia, P.A. p. 85--118.

Holland, P.T. 1996. Glossary of Terms Relating to Pesticides. Hort Research Institute of New Zealand Ltd, Private Bag 3123, Hamilton. New Zealand. p. 1.168-1.193 .

Kanazawa, J. 1979. Measurement of the bioconcentration factors of pesticides by freshwater fish and their correlation with physicochemical properties or acute toxicities. National Institute of Agricultural Sciences. Japan. 12: 417--424.

Kanazawa, J., D. Kilin, Sutrisno, dan S. Orita. 1985. Residue of Diazinon in Rice Plant and Paddy Soil. Penelitian Pertanian 3(2): 83--84.

Litchfield, Jr, J.T. and F. Wilcoxon. 1949. A simplified method of evaluation dose-effect experiments. $J$. Phar. Exp. Therap. 56: 89--113.

Livingston, R.J. 1977. Review of current literature concerning the acute and chronic effect of pesticides on aquatic organism. CRC Crit. Rev. Environment Control. $7(4): 325$.
Natawiguna, H. 1989. Pestisida dan Kegunaannya. Armico, Bandung. 95 pp.

Sastroutomo, S.S. 1992. Pestisida Dasar-Dasar dan Dampak Penggunaannya. Gramedia Pustaka Utama. Jakarta.

Spacie, A. and J.L. Hamelink. 1985. Bioaccumulation. In: Fundamentals of Aquatic Toxicology, Method, and Application. G.M. Rand and S.R. Petrocelli (Edt.). Hemisphere Publishing Corporation. WashingtonNew York-London. p. 495--525.

Soerjani, M. 1990. Kecenderungan penggunaan pestisida di Indonesia dan berbagai negara Asia serta dampaknya terhadap lingkungan. Dalam: Perlindungan Tanaman Menuju Terwujudnya Pertanian Tangguh dan Kelestarian Lingkungan. PT Agricon-Bogor. p. 719--745.

Sunarjo, P.I. 1990. Dampak pestisida pada biota perairan. Tinjauan Hasil Penelitian Jurusan Hama dan Penyakit Tumbuhan. Fakultas Pertanian Universitas Hasanuddin. $14 \mathrm{pp}$.

Tanjung, D. 1982. The Acute Toxicology and Histopatology of Brook Trouth (Salvelinus frontalis Mitch.) Exposed to Aluminium in Acid Water. Fordam University. New York City. Disertasi. 176 pp.

Tsuda, T, S. Aoki, M. Kojima, and T. Fujita. 1992. Accumulation and excretion of pesticides used in golf courses by carp (Cyprinus carpio) and willow shiner (Gnathopogon caerulescens). Comp. Biochem. Physiol. 101C: 63--66.

Wardoyo, S.T.H. 1977. Panduan uji biologi untuk evaluasi toksisitas minyak dan dispersan. Proyek Studi Lingkungan Hidup. 16 pp.

Waren, C.E. 1971. Biology and Water Polution Control. W.B. Sounders Co. Philadelpia. p. 67--113

Wudianto, R. 1997. Petunjuk Penggunaan Pestisida. Penebar Swadaya. Jakarta. 116 pp. 